\title{
Capabilities for What? Developing Sen's Moral Theory For Communications Research
} Author(s): Nick Couldry

Source: Journal of Information Policy, Vol. 9 (2019), pp. 43-55

Published by: Penn State University Press

Stable URL: https://www.jstor.org/stable/10.5325/jinfopoli.9.2019.0043

Accessed: 01-10-2019 15:34 UTC

JSTOR is a not-for-profit service that helps scholars, researchers, and students discover, use, and build upon a wide range of content in a trusted digital archive. We use information technology and tools to increase productivity and facilitate new forms of scholarship. For more information about JSTOR, please contact support@jstor.org.

Your use of the JSTOR archive indicates your acceptance of the Terms \& Conditions of Use, available at https://about.jstor.org/terms

This article is licensed under a Creative Commons Attribution-NonCommercialNoDerivatives 4.0 International License (CC BY-NC-ND 4.0). To view a copy of this license, visit http://creativecommons.org/licenses/by-nc-nd/4.0/. 


\title{
CAPABILITIES FOR WHAT?
}

\section{Developing Sen's Moral Theory For Communications Research}

\author{
Nick Couldry
}

\begin{abstract}
This article reviews debates about the application of Amartya Sen's capabilities theory to the understanding and regulation of media and communications. It argues that Sen's insistence on the complexity of ethical reasoning, and the underlying complexity of "the good," makes the capabilities approach the most suitable general approach for considering what media justice is. In particular, the advantages of Sen's approach compared with Martha Nussbaum's specification of particular human capabilities are discussed. Possible supplements of capabilities thinking by the concept of recognition are also discussed, and their limits noted.
\end{abstract}

Keywords: capabilities, communications, ethics, recognition, complexity

Capabilities is a topic long overdue for broader attention by researchers in media communications and cultural studies: there have been only a few exceptions to this neglect. But the wider communications field can no longer afford to ignore what for some decades has been a major area of debate in economics and philosophy, and a concept influential in development studies and education. The only excuse for mainstream failure to engage with this topic is its difficulty! I hope here to add something useful to this debate.

For reasons that will become clear, I am going to anchor my comments in the approach to capabilities of Amartya Sen, not that of Martha Nussbaum. When we ask why it is that the capabilities approach is so helpful to research in media and communications, it is essential to take a position on the various options for pursuing that approach that are

Nick Couldry: London School of Economics and Political Science, Department of Media and Communications; British Library of Political and Economic Science

JOURNAL OF INFORMATION POLICY, Volume 9, 2019

This work is licensed under Creative Commons Attribution CC-BY-NC-ND 
available. It is Sen's approach that, I believe, has the greater promise, but justifying this requires thinking in some detail about the sorts of theoretical move Sen was trying to make when nearly 40 years ago (in a speech on "Equality of what?" in May 1979 at Stanford) ${ }^{\mathrm{I}}$ he first introduced the term "capability" into moral philosophy and debates about justice.

Sen's basic goal was to pull economics back to its fundamental terrain of ethics. In his 1987 book On Ethics and Economics, Sen insists on a view of "social achievement" that "cannot stop short at some arbitrary point like satisfying 'efficiency'." Instead, that assessment "has to be more fully ethical [which means] take a broader view of the good." ${ }^{2}$ Although in that passage he does not make a specific link to capabilities theory, which, in sum, is the route Sen's work offers to enrich our thinking about "the good." Sen wanted to develop an account of the good, which is more attuned to the actual complexity of the world and the actual complexity of how human actors think about value. Both, Sen argues, are much broader than how economists have come to think about the world and specifically think about the values that orient economic and social practice. The term "capabilities" is twinned for Sen with another term "functionings": that is, states of a human life that are potentially valued, and capabilities being the possibilities that individuals have of achieving such valued states.

Capabilities theory then is a theory of the good that lies within reach of human beings, but one that is closely tied to advancing our thinking about not only the good, but also, in some sense, justice or at least injustice. But Sen's full position on the concept of justice only emerged much later. One thing that follows from all this is that, because capabilities theory is a theory of the good, it is irrelevant to criticize Sen for not doing what he never aims to do, for example, for failing to provide a sociological theory of how people come to have "capabilities." In what follows, I will explain the philosophical underpinnings for potential policy developments of the capabilities approach: as a media and social theorist, I must leave exploration of the direct policy implications to those with more policy expertise, but I hope that, in spite of its abstractness, what follows will prove a useful starting point for further debate in the information policy field.

\footnotetext{
I. Sen, "Equality of What?"

2. Sen, On Ethics and Economics, 4.

3. Zimmermann.
} 


\section{Paths not Taken}

It is important to remember at the start that Sen's approach was an emphatic rejection of two other approaches in moral thinking, which were highly dominant at the time he was making this move. ${ }^{4}$ First was utilitarianism (so dominant for decades as a philosophical background to economics), but also, just as important, John Rawls' theory of justice, including Rawls' idea that there is a set of primary goods, which are "necessary means" to achieving whatever ends human beings have.' Sen opposed both these approaches for a fundamental reason, which was his belief in adapting moral theory to the reality of human diversity.

The distinctiveness of Sen's approach is clear from his key essay in The Quality of Life. There he already defines functionings as "the various things he or she manages to do or be in leading a life." This already brings in two types of complexity of scope and scale: both doing and being (expanding the scope of good as a concept), and the duration of a whole life, a scale across which we really can expect a diversity of goods to become more or less valued. But Sen goes further and insists, against utilitarianism, on a more fundamental heterogeneity: he insists that one valuable functioning is freedom, including the freedom precisely to choose between goods or functionings. From this it follows that the quality of one's life cannot simply be assessed by reference to what state one has actually achieved; its evaluation must be related also to what one has chosen to achieve, or not to achieve. But such choices are inherently diverse. This is why, in Sen's view, Rawls' approach to primary goods ignores, as he puts it, the complexities that flow from "the fundamental diversity of human beings." 7

But already Sen was clear that the fundamental plurality of goods and the necessary lack of full convergence in how people freely choose among the functionings available to them means something wider too: that what is just cannot, even in principle, be exhaustively resolved by supposedly just processes of rational deliberation oriented to reaching a single definitive distribution of a defined set of primary goods. Sen defends an openly inductive approach to finding out what sorts of things, and what sorts of arrangements of things, comprise the functionings that actual human

\footnotetext{
4. Srinivasan, 458-59.

5. Rawls, 93.

6. Sen, "Equality of What?," $3 \mathrm{I}$.

7. Sen, Inequality Reexamined, 8.
} 
beings are likely to value and from which they will choose their priorities. As he argues, ${ }^{8}$ we can opt for the capabilities approach without needing to resolve all the questions of relative weightings between goods, because they can never be fully resolved; they involve an irreducible plurality. Sen therefore, from the beginning, opposes the very idea of a complete theory of justice. And underlying this, of course, is Sen's inclination toward something like an Aristotelian view of ethics that starts out from what values are found in the world, and does not believe, as the Kantian tradition does, in the possibility of building up those values foundationally from a comprehensive rational argument.

And this incidentally for me is the major problem, as some contributors to the capabilities debate in communications propose, by using Rainer Forst's recent revival of Kantian procedural rationalism as a way of refining or improving Sen. There is a lot more to say about that point of course, but my point is more about the Kantian tradition than about Forst in particular. The more, I suggest, is not well suited to acknowledge the usefulness of the theory of the good that Sen offers. Indeed, in his foundational book The Right to Justification, Forst barely cites Sen (although, to be fair, Sen's The Idea of Justice was published after Forst's German edition) and his focus on justice is via Rawls. ${ }^{9}$ The Rawlsian approach (and Forst's too) risks not only circularity (in attempting to fuse principles of just process with specifying the states of affairs that would count as achieved social justice). Worse, it risks the overblown and misleading claim that it is even possible to resolve pluralities in the domain of value, pluralities that I suspect are irreducible. I have a lot of sympathy for Raymond Geuss's harsh dismissal of Rawls in his book Outside Ethics as a conservative and indeed a "parochial figure who ... pointed political philosophy in the wrong direction." ${ }^{\text {" }}$ But that is a controversy I do not need to go into further here.

It is not however that Sen doesn't care about issues of just process. As he argues in Development as Freedom "the achievement of social justice" involves practice that ensures people have the freedoms and capabilities to be heard in the processes, which weigh people's needs against each other. (James Bohman made a similar point in his 1997 essay that picked up the importance of Sen's capabilities approach for thinking about democracy.) $)^{\text {II }}$

\footnotetext{
8. Sen, "Equality of What?," 47.

9. Forst.

IO. Geuss, 39 .

II. Sen, Development as Freedom, I48. Compare Bohman.
} 
What is most important however about Sen's approach is something which has underlain the discussion so far: his insistence on analytic complexity.

Let's consider a little more the fundamental analytical moves that Sen made in developing the capabilities approach. Giles Moss offers a very helpful account here. ${ }^{12}$ To summarize, Sen argues (I) that preferences are not naturally occurring consequences of the goods that are objectively there to choose, but are themselves socially formed. Sen argues (2) that, because people start out from different bodily and other resources, they will, in any case, have different needs and so, as it were, "naturally different" preferences. And Sen argues (3) that, even if people have all chosen those same things, they may need different resources to actually achieve those things (so the effect of their preferences is not the same). All this on top of the question of choice: the basic fact (4) that, even with the same objective needs and resources, different human beings may simply choose different options from the range of functionings available to them. There is something immediately attractive for a field as suspicious of false universalism as communications in Sen's insistence on the diversity of value. But what is at issue is not subjective diversity for its own sake but, as David Hesmondhalgh argues for his proposed moral economy approach to development, the fact that Sen's theory is "pluralist" but not "relativist." 13

\section{What Is in Sen's Philosophical Tool-Box?}

So, after this long preamble, what potentially is in the box of functionings that we might value in relation to media and communications?

I put it this way because Sen's original formulations were rather different from the way we tend to talk about capabilities very often today, that is, as a set of human capacities that human beings should have or need, which is the way that Nussbaum has taken the capabilities approach. But, as Ingrid Robeyns pointed out, there is a major difference between Sen's original formulation of the capabilities approach summarized in his "Quality of Life" essay and Nussbaum's approach. ${ }^{14}$ Sen originally discussed capability as an abstract set of states of affairs: as "the capability of a person reflects

\footnotetext{
I2. Moss, 96-99.

I3. Hesmondhalgh, 2Io.

I4. Robeyns.
} 
the alternative combinations of functionings the person can achieve, and from which he or she can choose one combination." Is

This is quite different from understanding capabilities as embodied abilities or capacities, which is Nussbaum's approach. ${ }^{16}$ It is the flexibility of Sen's approach that makes it more useful. This is a big debate in itself, which I can't fully resolve here, but let me state baldly my sympathies with Sen's resistance to coming up with a definitive list of capabilities. Siding with Sen here is not a matter of choosing vagueness or lack of resolution. Rather, Sen's more flexible approach helps us think about an open and layered complexity, which is partly shaped by the variety of choices individuals make and which is premature to reduce in advance to a specific list of human capacities. This would however be of minimal relevance for the communications field if Nussbaum had already formulated some capabilities, which we could clearly and specifically apply to our field, but she has not, even though Hesmondhalgh has offered some starting points for how we develop Nussbaum's list of specific capabilities to media.

\section{Toward Specifying Capabilities for the Media and Communications Field}

So how, following Sen rather than Nussbaum, might we make progress in applying Sen's more open and inductive approach to achieve some specificity about the capabilities relevant to the media and communications field? We can be relaxed about allowing in quite a bit of heterogeneity to this set of valuable functionings, for example, including not just achieved goods, but also open-ended freedoms. ${ }^{17}$ We can also include some things we might feel are close to "basic goods" (such as some basic access to an Internet connection) and others that may not be basic, but are strongly desirable. We can also, I have suggested, develop our account of capabilities without too much concern with questions of what sorts of differences can be justified.

So, on my starting list for thinking about the set of functionings that we would all value in relation to media and communications (drawing in part on Nick Garnham's pioneering formulations back in the late 1990s) would be: (i) not being harmed/humiliated, misrepresented through media, (ii) basic access to media resources, (iii) opportunity to be in some broad

\footnotetext{
I5. Sen, "Equality of What?," 3I.

16. Nussbaum.

17. Sen, "Equality of What?," 33.
} 
sense represented as a type, plus (iv) if one wants the chance to speak, the opportunity of voice. ${ }^{18}$ But these are just the start. For in the digital era our relation to other human beings and wider society through media has become much more complex than in the mass media era that Garnham have envisaged in his essays. As Robin Mansell noted back in 2002, our whole thinking about our entitlements in relation to media has to move beyond "the dominant 'broadcast' mode of media provision." "' Which may mean that we need to orientate ourselves to different types of choice and different sites of choice in relation to communications from those that seemed set out for us in the era of limited channels and media flows that were relatively scarce rather than absolutely continuous and overlapping.

One possibility for supplementing Sen's emphatically diverse set of functionings that is of particular relevance to media is Axel Honneth's concept of recognition. The concept of recognition points to three levels in which human beings need to be recognized by each other if their lives are to have any integrity: the level of individual care and love, the level of moral agency, and most interestingly here, the level of recognition as a social actor. Or, as Honneth puts it in an essay called "Between Aristotle and Kant": where "the individual is recognized as person whose capabilities are of constitutive value to a concrete community." ${ }^{20}$ I find it striking that in Stephen Coleman and Giles Moss's interesting empirical exploration of what citizens might think of as capabilities (or capacities) that they would want governments to recognize in them; some of those capabilities are quite close to recognition. ${ }^{21}$ I would propose that people do need to find themselves recognized, at least indirectly, in the representations of the world that are presented to them as their "reality." It is a basic form of exclusion to be invisible, not so much individually, but as a type, or a nation, or a class, or an ethnicity, or a sexuality, in the narratives that purport to describe one's world and its actors.

As a philosopher, Honneth fits in well to my argument here because his approach is firmly Hegelian, not Kantian, in how he thinks about the relations between rationality, ethics, and social/institutional processes. For Honneth, "justice is the wellbeing of a society" (i.e., a super-personal largescale good), ${ }^{22}$ which is very different from saying, as Rawls does, that justice

\footnotetext{
I8. Garnham.

19. Mansell, 422.

20. Honneth, Misrecognition, I39.

2I. Coleman and Moss.

22. Honneth, "Recognition and Justice," 354.
} 
is the virtue of just institutions whose justice is defined by their processual qualities. Honneth, like Sen, has his sights set on what is the good, not on the grounding of justice in an institutional process which, Rawlsian-style, is capable of generating just decisions about justice.

But there are some problems also with using Honneth to round out capabilities theory for media and communications: in particular, his attempt to subordinate the distinction between economic and symbolic both under the ambit of his master concept, recognition! So Honneth wrote in 2004 that both "economic disadvantage" and "cultural deprivation" are aspects of the degrees "to which subjects can experience social disrespect or humiliation." ${ }_{23}$ To equate extreme poverty with mere disrespect seems to ignore entirely the notion of basic goods that Sen holds onto and to override important hierarchies between goods that are important to any notion of justice. Similarly, it is less clear in Honneth than in Sen what role freedom to choose plays in the concept of recognition, though we might perhaps go back to Hegel and build freedom into the concept of recognition.

What comes out again here, in the contrast with Honneth, is the importance of Sen's commitment to pluralism and complexity (of value) and his rejection, already clear from his earliest work on capabilities, of either overspecifying our conception of the good. (In this respect, perhaps Sen is closer to Nancy Fraser who insists on the values of both material resources and recognition.) But that needn't stop us adding in the concept of recognition (in its multiple dimensions) as capturing a further set of functionings that need to be part of any person's overall set of functionings from which they are free to choose. Some level of recognition in complex societies seems pretty close to a basic good, but exactly how, and at what level, is unresolved.

Introducing the concept of recognition into the capabilities approach to the discussion of media and communications enables the inclusion of other things that Sen doesn't talk about, such as listening-the need to be listened to-at least at key moments when one wants or needs to speak. That move has major importance in current debates in communications: I am thinking, for example, of Tanja Dreher's consistent work on listening in multicultural Australia and Hermann Wassermann's article on "the ethics of listening" in a complex conflicted society such as South Africa. ${ }^{24}$

23. Honneth, "Recognition and Justice," 352.

24. Dreher; Wasserman. 
What I am suggesting here, and what I already hinted at earlier, is that the appropriate place to introduce the concept of recognition into our understanding of the good is not as a rival concept to capability or functionings, but as a further element of the good, that is, as one aspect of the larger set of functionings that we value both generally and specifically in relation to media and communications, and from which we would want the opportunity to choose. This is more useful, I propose, than treating recognition purely as a process value that is required to ensure the justice of institutions.

There is a deeper reason too for adding in recognition to our picture of functionings and capabilities. This deeply relational good enables us to have a more credible sense of the many levels on which societal injustice works. As Panjak Mishra noted in a 2013 New York Review of Books review of Sen's recent work on India, ${ }^{25}$ part of the reason Sen has rejected traditional economic measures of societal success, such as growth rate and gross domestic product (GDP), is that they ignore other vital goods, such as those linked to education and the injuries to persons done by inequality itself. There is an echo here of debates on the fringes of political science, for example, Henry Milner's excellent if neglected book Civil Literacy from the early 2000 s on links between reducing economic inequality and increasing societal trust and, in turn, improving democratic functioning. ${ }^{26}$ We start to get a sense here of the huge interlocking complexity of the components of "the wellbeing of a society," which then needs to inform our sense of the sorts of functioning that are important for evaluating the capabilities that people have.

Once again, it is the openness of Sen's approach-his emphasis on capabilities as states of affairs that can be understood to operate on multiple levels and dimensions, rather than reduced exclusively to embodied capacities of individuals - it is this flexibility that helps us complicate our understanding of the multiple "goods" that matter in the media and communications of complex societies.

This sense of increasing analytic complexity that emerges, as we start to think with Sen (but with other thinkers too) is very important and salutary today in our field. There are at least two reasons for this. First, because the acknowledgement of complexity is necessary, if our normative prescriptions are to be adequate to the actual "plurality of legitimate

25. Mishra.

26. Milner. 
points of view" in complex societies, as Jean-Michel Bonvin puts it. ${ }^{27}$ One can also see a resonance here with the pluralist approach to value and critique by Luc Boltanski, particularly his work with Laurent Thévenot. ${ }^{28}$ The second reason why Sen's approach is salutary derives from the huge tensions between inherited normative frameworks and the accelerated development of new information infrastructures. Robin Mansell was the first to set out the overall problem, which flows from the growing tension between imposed system autonomy and still desired human autonomy on some scale, whether individual or collective. ${ }^{29}$ In 2017 , she put things even more starkly when she insisted on the need for a new kind of dialogue about how these tensions will affect "what humans will do in their lives in the future." ${ }^{\circ} \mathrm{A}$ wave of new books is starting to open out this dialogue. ${ }^{31}$

\section{Conclusion: The Advantage of Complexity}

Let me try therefore, by way of conclusion, to explore a little further more why we need analytic complexity in the domain of the good, and particularly the good in relation to the digital and the datafied.

Sen has always insisted on the layered complexity of values. So if, as he put it, "freedom cannot be fully appraised without some idea of what a person prefers and has reason to prefer" (and of course the good can't be grasped without including within it some notion of freedom), then it is the interrelations between values that are crucial, what Sen calls in the same chapter a person's "entire system of values, including values about values." ${ }_{22}$ This emphasis on second- and higher-order values, values about values: Isn't this particularly important at a time not just of tension between values, but a time when a higher level of normative complexity is being written out by the rapid advance of automated evaluations, delegated algorithmic systems for categorizing and valuing human beings against each other for multiple purposes? An era of automated inequality is a time that requires us above all to hold onto choices about choices,

27. Bonvin.

28. Boltanski and Thévenot.

29. Mansell, Imagining the Internet.

30. Mansell, "Inequality and Digitally Mediated," 158.

3I. For example, Frischmann and Selinger; Lanier. See also Couldry and Mejias (forthcoming 2019).

32. Sen, Rationality and Freedom, 5-6. 
values about values. ${ }^{33}$ In such a time, we need to know why some of our values, the values that certain institutional forces are happy to delegate to automation, have value.

Datafication (the requirement, not just the possibility, that every variation in the texture of human experience be translated into data for counting and processing) is inclining the social terrain-indeed is reconfiguring the social terrain -into a space formed in large part by automated choice, or what legal scholar Karen Yeung calls "hypernudge." ${ }^{34}$ As such, this attempt to automate many domains of choice need not reduce the complexity of our ethical lives as human beings, for we can try to stand to the side of this. But we have no choice but to acknowledge the force with which this reengineering of practical and ethical choice is becoming woven into the organization of social and economic transactions, converting much of what have not been transactions into the transactional, into the capturable. A transformation that cannot be understood at all without grasping the new political economy of datafication, and specifically the political economy of the platforms across which so much of what counts as social life is being performed. If, to put it bluntly, platforms are machines for producing "social life" for capitalism (under the governance of capitalism), then we need a clear sense of the embedded values and notions of the good that are likely to be overlain by this new production.

Some are unconcerned by all this: hoping perhaps, like Kevin Kelly, for a species-level transformation toward a new collective intelligence; or arguing, like Jeremy Rifkin, that while there are risks in this transformation, the normative ground has already been ceded and values, such as privacy, formed in an older political economy and social order, have been lost irretrievably. ${ }^{35}$ But, as popular historian and futurist, Yuval Harari, points out, the choices about choices involved here cannot be so easily swept away. Indeed, Harari goes further and argues that "a critical examination of Dataist dogma is likely to be not only the greatest scientific challenge of the 2Ist century, but also the most urgent political and economic project." ${ }^{36}$ If so, then we have never needed more a sharp focus on what counts as good, on what complex, layered states of affairs cannot be regarded as good: states of affairs that threaten the fragile and deeply interconnected

33. Eubanks.

34. Yeung, II8-36.

35. Kelly; Rifkin.

36. Harari, 459. 
mass of possibilities that we would want to include among the conditions of a good life. This is a time indeed to reject what no less a figure than Pope Francis in his 2015 Encyclical called the "reductionism" of "the technocratic paradigm. ${ }^{37}$

As Amartya Sen noted 20 years ago, "the achievement of social justice depends not only on institutional forms (including democratic rules and regulations), but also on effective practices." ${ }^{8}$ Surely one such effective practice is how we think about and parse "the good" in all its complexities. As our grid of norms becomes ever more stretched and challenged by our fast-changing infrastructure for processing data and information, we need robust support, not so much toward the impossibly large goal of creating a just society, but more basically to hold onto an adequately complex account of the good, and its relation to the freedom to choose in a complex world. That is why our field needs more than ever, the capabilities theory of Amartya Sen.

\section{BIBLIOGRAPHY}

Bohman, James. Democracy without Borders. Cambridge: MIT Press, 2007.

Boltanski, Luc and Laurent Thévenot. On Justification, Princeton: Princeton University Press, 2006.

Bonvin, Jean-Michel. "La Démocratie dans l'approche d'Amartya Sen." L'Economie Politique 27, no. 3 (2005): 24-37.

Coleman, Stephen, and Giles Moss. "Studying Real-Time Audience Responses to Political Messages: A New Research Agenda." International Journal of Communication I2 (2018): I696-I7I4.

Couldry, Nick, and Ulises Mejia. The Costs of Connection: How Data is Colonizing Human Life and Appropriating It for Capitalism. Palo Alto: Stanford University Press, 2019.

Dreher, Tanja. "Listening Across Difference: Media and Multiculturalism Beyond the Politics of Voice." Continuum 23, no. 4 (2009): 445-58.

Eubanks, Virginia. Automating Inequality. New York: St Martin's Press, 2018.

Forst, Rainer. The Right to Justification. New York: Columbia University Press, 2014.

Frischmann, Brett, and Evan Selinger. Re-engineering Humanity. Cambridge: Cambridge University Press, 2018.

Garnham, Nicholas. "Amartya Sen's 'Capabilities' Approach to the Evaluation of Welfare: Its Application to Communication." Javnost 4, no. 4 (1997): 25-34.

Geuss, Raymond. Outside Ethics. Princeton: Princeton University Press, 2005.

Harari, Yuval. Homo Deus. London: Vintage, 2017.

Hesmondhalgh, David. "Capitalism and the Media: Moral Economy, Well-being and Capabilities." Media Culture \& Society 39, no. 2 (2017): 202-18.

37. Pope Francis, 66-7.

38. Sen, Development as Freedom, 159. 
Honneth, Axel. "Recognition and Justice: Outline of a Plural Theory of Justice." Acta Sociologica 47, no. 4 (2004): 35I-64.

Honneth, Axel. Misrecognition. Cambridge: Polity, 2007.

Kelly, Kevin. The Inevitable. New York: Penguin, 2016.

Lanier, Jaron. Ten Arguments for Deleting Your Social Media Accounts Right Now. London: Bodley Head, 2018.

Mansell, Robin. "From Digital Divides to Digital Entitlements in Knowledge Societies." Current Sociology 50, no. 2 (2002): 407-26.

. Imagining the Internet. Oxford: Oxford University Press, 2012.

. "Inequality and Digitally Mediated Communication: Divides, Contradictions and Consequences." Javnost 24, no. 2 (2017): I46-6I.

Milner, Henry. Civic Literacy. Boston: University of New England Press, 2002.

Mishra, Panjak. "Which India Matters?” New York Review of Books, November 2I, 2013.

Moss, Giles. "Media, Capabilities and Justification." Media Culture \& Society 40, no. I (2017): 94-I09.

Nussbaum, Martha. Creating Capabilities. Cambridge: Harvard University Press, 2013.

Pope Francis. Encyclical on Climate Change and Inequality. New York: Melville House, 20I5.

Rawls, John. A Theory of Justice. Oxford: Oxford University Press, I972.

Rifkin, Jeremy. The Zero Marginal Cost Society. New York: St. Martin's Press, 2014.

Robeyns, Ingrid. "The Capability Approach: A Theoretical Survey." Journal of Human Development 6, no. I (2005): 93-117.

Sen, Amartya. On Ethics and Economics. Oxford: Oxford University Press, 1987.

. Inequality Reexamined. Oxford: Oxford University Press, 1992.

. "Equality of What?" In The Quality of Life, edited by Martha Nussbaum and Amartya Sen, Oxford: Oxford University Press, I993.

- Development as Freedom. Oxford: Oxford University Press, 1999.

Rationality and Freedom, Oxford: Oxford University Press, 2002.

Srinivasan, Sharath. "No Democracy Without Justice: Politcal Freedom within Amartya Sen's Capability Approach." Journal of Human Development 7, no. 3 (2007): 457-80.

Wasserman, Herman. "Journalism in a New Democracy: The Ethics of Listening." Communicatio: South African Journal for Communication Theory and Research 39, no. I (2013): 67-86.

Yeung, Karen. "Hypernudge': Big Data as a Mode of Regulation by Design." Information Communication and Society 20, no. I (2017): II8-36.

Zimmermann, Benedicte. "Pragmatism and the Capabilities Approach: Challenges in Social Theory and Empirical Research." European Journal of Social Theory 9, no. 4 (2006): $467-84$. 